\title{
Features of urban agglomerations formation in the system of the Black Sea region
}

\author{
Iryna Azhaman ${ }^{1}$, Olha Kambur ${ }^{2}$, Anastasiia Pandas ${ }^{2, *}$, Nataliia Petryshchenko ${ }^{2}$, and \\ Nataliia Serohina ${ }^{2}$ \\ ${ }^{1}$ Odessa State Academy of Civil Engineering and Architecture, Educational and Scientific Institute of \\ Business and Information Technologies, Department of Management and Marketing, 4, Didrihsona \\ Str., Odessa 65029, Ukraine \\ ${ }^{2}$ Odessa State Academy of Civil Engineering and Architecture, Educational and Scientific Institute of \\ Business and Information Technologies, Department of Economics and Entrepreneurship, 4, \\ Didrihsona Str., Odessa 65029, Ukraine
}

\begin{abstract}
.
Research background: The structure of the urban agglomeration is quite dynamic and requires comprehensive consideration and research. Despite the initial stage - formation, urban agglomerations in the system of the Black Sea region have the characteristics of developed systems. The paper evaluates the starting position of urban agglomerations of the Black Sea region, based on the coefficient of development, coefficient and index of agglomeration. Emphasis is placed on the consideration of urban agglomerations in the context of the recreational component. The vector of development changes from the central areas to the suburban area with the active transformation of the spatial structure. A system of integrated territorial development of urban agglomerations is needed, taking into account their specific spatial components.

Purpose of the article: Research of modern processes that form urban agglomerations. Study of positive and negative effects of agglomeration. Identification of the main factors influencing the agglomeration process of the Black Sea region.

Methods: The following methods were used to solve the problems: analysis, synthesis, systematization, comparison, rating.

Findings \& Value added: Development of urban agglomerations of the Black Sea region is planning and coordination of further sustainable development of agglomeration space, including development of plan for construction, planning and coordination of infrastructure construction, search for funding sources. This will intensified investment, give impetus to the development infrastructure, economic environment and recreational component.
\end{abstract}

Keywords: urban agglomeration; recreational agglomerations; region

JEL Classification: $O 18 ; P 25 ; R 11$

\footnotetext{
*Corresponding author: anastasypandas@gmail.com
} 


\section{Introduction}

Modern urbanization is due to the transformation of the functions of the surrounding areas. This complex process accompanies the emergence of urban agglomerations, which are the epicentres of institutional modernization. Activation of the process is stimulated by industrialization and European integration processes [1]. The vector of development is changing from the central areas to the suburban area with an active change in the spatial structure, the formation of the real estate market, the development of socio-economic and infrastructural components. The emergence of suburbs, pendulum migration, blurring the boundaries of the social space of the city, makes the study of urban agglomeration processes extremely necessary.

Studies of European experience have shown that "the adoption of EU standards in Ukraine will lead to significant transformations in all spheres of human life, including the structure of urban, rural and suburban populations" [2].

Lower-level territorial units in the area of influence of a large city must meet modern requirements. However, there is a chaotic, poorly controlled process of urbanization of recreational centres due to the lack of aging of existing project documentation. The necessary system of integrated territorial development of urban agglomerations is balanced between resort, recreational and other possible options for the use of territories. Their recreational and residential components should be monitored with further development of preventive measures to optimize the functional and planning structure of cities, improve infrastructure and management mechanism. Improvement of spatial development of agglomerations should take place, according to the following positions:

1. Development of a comprehensive and detailed analysis of the current state of the region (creation of a reference plan).

2. Understanding the direction of spatial development of agglomerations on the basis of sustainability.

3. Rethinking territorial zoning and zoning, taking into account the experience of development.

4. Conducting an in-depth analysis of the development of transport infrastructure [3].

5. Development of a new strategy for socio-economic development of recreational urban agglomerations.

\section{Definitions}

M. Babayev, the concept of "urban agglomeration" means a compact cluster of settlements, which is based on a certain city, united into a single whole by intensive economic, labour, cultural and recreational ties [4].

According to E. Boze, the urban agglomeration is characterized by the integrity of production and settlement systems, and the integrity of markets (labour, real estate, land), as well as the level of their functional connectivity [5].

That is, in essence, the agglomeration arises on the basis of a large city and creates a significant area of urbanization, absorbing adjacent settlements. The question of belonging of cities and villages to a certain agglomeration depends on the connection of their inhabitants with the capital. The residents living in small-populated communities adjacent to urban centres are the most satisfied with their communities than larger rural communities farther from urban centres [6].

The city-centre of the agglomeration must have a high internal potential, meeting the needs of the city and surrounding areas [7]. Agglomeration is appropriate if it brings agglomeration savings: the positive benefits of its formation more than the additional costs associated with its occurrence. The development of modern urban agglomerations is 
manifested in the intensive socio-economic, technological and infrastructural development of large urban centers and adjacent suburban areas.

Agglomeration economies have been analysed mainly with respect to their impact on regional growth and development and rarely accounted for as a determinant of sectoral specialisation, even when the sectoral dimension has been explicitly taken into account [8, 9]

To determine the size and development trends of urban agglomerations, the indicators shown in Figure 1.

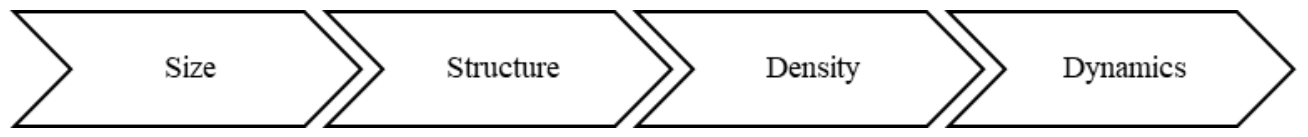

Fig. 1. Indicators for determining the development and development trends of urban agglomerations

The most common type of agglomeration is monocentric, in which the development of the suburban area takes place around the centres and is accompanied by the creation of compact, densely populated, multifunctional areas connected by a large network of transport and infrastructure [10].

The development of the transport system requires investment. Concessions can be used for the reconstruction and expansion of transport routes, the development of modern infrastructure and its support, as well as for the improvement of quality of transport services [11].

However, the current stage of development of urban agglomerations forms a new type of scattered or radial agglomeration forms.

The positive effect of agglomeration in the economic sphere is:

- formation of a capacious market of goods and services, both private and public;

- development of industrial and social infrastructure (system of urban transport, health care, education, utilities, etc.);

- concentration of scientific and technical resources and active implementation of innovations, etc.;

- tendency to cluster [12].

The co-location in an agglomeration has a positive influence on a firm's innovative performance; and firms benefit heterogeneously from agglomerations, with benefits being distributed asymmetrically. Agglomeration gains exist but not all firms benefit equally.

However, the agglomeration has negative consequences in the economic sphere:

- complication of transport connections, remoteness of communication objects;

- ecological load [13];

- deterioration of housing use;

- increasing the distance to the sources of heat, energy, water supply, treatment facilities, which causes an increase in the average cost of production;

- increasing the income gap between the centre and the periphery, etc. [14];

- the analysis shows robust evidence of positive spill overs of fast-growth firms on the labour productivity of non-fast-growth firms in the same industry and region.

However, the externalities in relation to the employment growth of non-fast-growth firms are negative, suggesting labour poaching and local competition effects [15].

The development of an urban agglomeration is usually based on the natural, historical, economic and socio-cultural features of the core city.

Urban agglomerations of Ukraine are formed near large cities of Ukraine and in industrial regions. Now in Ukraine there are 23 agglomerations. About 17 million people, $36 \%$ of the country's population, live in the 19 largest urban agglomerations of Ukraine.

The Black Sea region is a special natural system, an area of investment attractiveness, characterized by significant recreational potential and diversity of tourist flows. The current 
epidemiological situation has significantly reduced tourist flows, but the effect of delayed demand should be expected [16].

The main feature of the Ukrainian Black Sea coast is the favourable location, which largely determined the structure and type of economic specialization of the region. In the interregional division of labour, the Ukrainian Black Sea coast specializes in foreign trade, maritime transport, shipbuilding and ship repair, resort and recreational economy and tourism, diversified agriculture, development of Black Sea shelf resources. Then local historical-cultural heritage may function as a pull factor that is positively correlated with the local creative economy. This leads to important policy lessons on creative-cultural complexes [17].

Significant export potential is concentrated in the leading port-industrial centres (Odessa, Mykolayiv, Kherson, etc.). The connection of ports to European sea transport routes increases their investment attractiveness [18].

Analysing the Black Sea region look Odessa, Mykolayiv, Kherson agglomeration.

Table 1. Agglomeration structure of the Black Sea region

\begin{tabular}{|c|c|c|c|c|}
\hline $\begin{array}{c}\text { The name } \\
\text { of the } \\
\text { agglomeration }\end{array}$ & $\begin{array}{c}\text { Population on } \\
\text { January 1, 2018, } \\
\text { thousands of } \\
\text { people }\end{array}$ & $\begin{array}{c}\text { Area, } \\
\text { thousand } \\
\mathrm{km}\end{array}$ & $\begin{array}{c}\text { Population } \\
\text { density, } \\
\text { persons } / \\
\mathrm{km}^{2}\end{array}$ & Main cities \\
\hline Odessa & 1546,6 & 3,99 & 158,1 & $\begin{array}{c}\text { Odessa, Bilyaivka, } \\
\text { Chernomorsk, Teplodar, } \\
\text { Yuzhne }\end{array}$ \\
\hline Mykolayiv & 591,3 & 3,04 & 194,5 & Mykolayiv \\
\hline Kherson & 583,8 & 7,41 & 78,8 & Kherson, Hola Prystan \\
\hline
\end{tabular}

These data show that the Odessa agglomeration has a fairly high population density per $1 \mathrm{~km}^{2}$. This is due to the attractiveness of this spatial unit for labour migration, as the production and tourism components of the Odessa agglomeration are the most developed among the above, due to the presence of numerous resorts, three major ports - Odessa, Yuzhne and Chernomorsk - and a significant number of related activities. Odessa port is one of the largest passenger terminals in the Black Sea, which can serve up to 4 million tourists a year. Research conducted by scientists [19] indicates a high level of organizational and managerial function in the Odessa region.

The territory of the Odessa agglomeration, first of all, its coastal strip, has a high recreational natural resource potential, in particular, warm climate, sea beaches, therapeutic muds, mineral water springs, brine of estuaries and lakes, unique natural complexes, picturesque landscapes, hunting and fishing grounds, water areas of estuaries, lakes, seas, suitable for water sports and recreation. The combination of all these factors creates conditions that are extremely favourable for the organization of recreation and development of the spa industry [20].

The largest indicator of population density in the Mykolayiv agglomeration which has the smallest area. As the coastal zone of the Mykolayiv agglomeration has the smallest extent, the tourist component here is not so developed, as in the Odessa agglomeration. The population density is explained by the presence of two ports and a shipyard, which includes three shipyards, which provides jobs. The Mykolayiv agglomeration has powerful recreational and tourist resources not only natural, but also anthropogenic character, among which it is possible to note historical and cultural resources, namely, monuments of history, architecture, archaeology, ethnography, and also the places connected with a life and 
activities of prominent people. But at present these resources are not used rationally and need further development.

The Kherson agglomeration is distinguished by the focus on the activities of recreational areas, because in addition to a fairly long coastline in this area is significantly developing green tourism in the steppe areas. Tourist flows have been gradually increasing in recent years, but among the negative factors hindering the development of tourism are the unsatisfactory condition of transport infrastructure and collective accommodation, as well as the lack of highly qualified staff.

Consider the strengths and weaknesses of urban agglomerations in the system of the Black Sea region, as well as opportunities and threats in the table SWOT-analysis (Table 2). The formed indicators reflect the development of sintering processes at the present time, indicating the prospects for future development.

The development of agglomeration processes in recreational areas is a complex and multilevel process that includes the emergence of new and transformation of existing settlements, changes in their functional structure, under the influence of a powerful cityforming factor - the recreational system. Structural and dynamic features of the recreational agglomeration of urban tourist and recreational centres are their integration into a single agglomeration system. The objective consequence of this process is the complication of the territorial and functional structure of the region and the subsequent formation of a special functional type of agglomerations specializing in the performance of recreational functions.

Under the recreational agglomeration means a system of urban settlements with a cityforming function of recreation, combined with industrial, logistical, organizational and managerial links and flows of vacationers, acting as a separate functional type of urban agglomerations.

One of the main features of recreational agglomerations is the presence of recreational and residential components of such systems.

Table 2. SWOT-analysis of urban agglomerations in the system of the Black Sea region

\begin{tabular}{|c|c|c|}
\hline 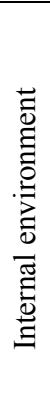 & $\begin{array}{l}\text { Strengths (properties that give advantages) } \\
\text { 1. Various natural and recreational resources } \\
\text { 2. Favourable climate } \\
\text { 3. Historically formed market of tourist } \\
\text { services } \\
\text { 4. Availability of transport links }\end{array}$ & $\begin{array}{l}\text { Weaknesses (properties that weaken the } \\
\text { project) } \\
\text { 1. Seasonality of agglomeration expansion. } \\
\text { 2. Weak development of transport } \\
\text { infrastructure. } \\
\text { 3. Irrational use of territorial resources of } \\
\text { the recreational zone. } \\
\text { 4. Imperfection of the legal framework and } \\
\text { lack of regulation at the state, regional } \\
\text { and local levels through legislation }\end{array}$ \\
\hline 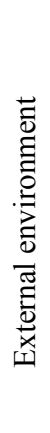 & $\begin{array}{l}\text { Opportunities (external probable factors that } \\
\text { provide additional opportunities to achieve the } \\
\text { goal) } \\
\text { 1. More rational use of spatial resources } \\
\text { 2. Organization of a constant tourist flow } \\
\text { throughout the year } \\
\text { 3. Creating a favourable investment climate } \\
\text { for entrepreneurs } \\
\text { 4. Development of a target program for the } \\
\text { development of urban agglomerations in } \\
\text { the system of the Black Sea region }\end{array}$ & $\begin{array}{l}\text { Threats (external probable factors, } \\
\text { which can complicate achievement } \\
\text { targets) }\end{array}$ \\
\hline
\end{tabular}




\section{Methods}

A comprehensive study of this issue should be based on a retrospective review of the agglomeration processes of the Black Sea region with the identification of basic patterns and should include the main aspects:

1. Analysis of the current state of development of urban agglomerations.

2. Assessment of the level of development of urban agglomerations that reflect integrated indices. The basis is the characteristics of the starting position of the urban agglomeration, based on the coefficient of development of the agglomeration, the coefficient and the index of agglomeration.

3. Study of the structure of urban agglomerations, in the context of recreational orientation.

\section{Results}

The urban agglomeration is a very dynamic structure and in the process of its development undergoes various changes. The appearance of urban agglomerations is changing so rapidly that it is not possible to develop a single universal scheme that could be the basis for managing the urban development of any agglomeration. The basis of the urban agglomeration as a complex conglomeration of central, peripheral settlements, transport, communication and other connections between them is a network of formal and informal interactions that determine the configuration of the structural elements of the agglomeration.

Despite the initial stage of development, urban agglomerations in the system of the Black Sea region have the characteristics of fairly developed systems. Therefore, the main issues are the study of the development of the agglomeration, their role in the long-term development of the region. The main feature of urban agglomerations in the system of the Black Sea region is the development of suburbanization. This is due to the fact that the city is not able to provide conditions for comfortable living: environmental load, inflated real estate, high density of residential areas, exacerbation of socio-economic problems. The considered agglomeration processes emphasize the need to analyse a set of factors: naturalgeographical, economic, socio-demographic, infrastructural, environmental, cultural and entertainment. There is a need for coordinated development of territories, reduction of administrative barriers, stimulation of investment attractiveness for the effective formation of urban agglomerations in the system of the Black Sea region.

Urban agglomeration processes must have a holistic vision of prospects and a clear development plan, taking into account the complexity of the socio-economic structure and functional connections of the city and suburban spatial zones. However, in practice there is a spontaneous growth of urban agglomeration without taking into account the specifics of concentration, specialization, diversification of economic functions, sectoral, territorial and spatial division of labour. The development of the urban agglomeration is associated with the emergence of difficulties in controlling its territory, increasing the economic costs of reproduction of the necessary infrastructure, as well as the management of all these elements.

Assessment of the development of agglomerations is based on the indicators of the settlement system - the population in settlements of different types and density characteristics. An indicator of internal connectivity within the agglomeration is transport accessibility.

Characteristics of the starting position of the urban agglomeration is carried out according to several indicators listed in table 2 . 
Table 3. Indicators of the starting position of urban agglomerations of the Black Sea region

\begin{tabular}{|l|c|c|c|}
\hline \multirow{2}{*}{$\begin{array}{c}\text { Agglomerations of } \\
\text { the Black Sea } \\
\text { region }\end{array}$} & \multicolumn{3}{|c|}{ Indicators for assessing the position of the urban agglomeration } \\
\cline { 2 - 4 } & $\begin{array}{c}\text { The coefficient of } \\
\text { development of the } \\
\text { agglomeration }\end{array}$ & $\begin{array}{c}\text { Coefficient of } \\
\text { agglomeration }\end{array}$ & Agglomeration index \\
\hline Odessa & 6,39 & 0,21 & 0,1 \\
\hline Mykolayiv & 0,48 & 0 & 0 \\
\hline Kherson & 0,68 & 0,01 & 0,05 \\
\hline
\end{tabular}

The coefficient of development of the agglomeration is calculated as follows:

$$
C_{d e v}=P_{a} \times(C \times c+N \times n)
$$

$P_{a}$ - population of the urban agglomeration (million people);

$C$ - the number of cities in the urban agglomeration;

$N$ - the number of urban settlements in the urban agglomeration;

$c$ - the share of urban population in the population of urban agglomerations;

$n$ - the share of the population of urban settlements in the population of urban agglomerations [16].

Speaking about the efficiency of the agglomeration settlement system, the coefficient of development $\left(C_{d e v}\right)$ should be more than 1 .

Analysing the data in Table 2, the coefficient of development of the agglomeration is higher than 1 only in the Odessa agglomeration, which indicates the level and reliability of the position as an agglomeration. Lower rates in Mykolayiv and Kherson agglomerations, this is due to the small number of urban settlements in them. It should be noted that in these agglomerations there are many large settlements that can actually be considered as urban settlements. With the intensification of territorial and administrative transformations, which will increase the number of urban settlements, the rate of development of the agglomeration will be significantly higher. Then the development of agglomerations will change - the intensification of ties within the formed agglomeration, the contraction of the population in them and, accordingly, the increase in the level of development will begin. To assess the level of development (maturity) of the agglomeration, the coefficient and index of agglomeration are considered.

The agglomeration coefficient characterizes the formation and development of the external environment of the territory and is calculated as the density of the network of urban settlements, attributed to the average shortest distance between them [21]:

$$
C_{a}=(C / S) \times L
$$

$C$ - the number of cities in the agglomeration;

$S$ - area of the agglomeration, $\mathrm{km}^{2}$;

$L-$ the shortest distance between city points, $\mathrm{km}$.

This ratio must be at least 0,1 . But for the Mykolayiv agglomeration it is uninformative as this agglomeration includes only one city settlement that makes influence of the shortest distance between city points incorrect.

Agglomeration index - the ratio of the urban population of the outer zone to the urban population of the whole agglomeration:

$$
\mathrm{Ia}=\mathrm{P} / \mathrm{Pa}
$$

$P$ - the urban population of the satellite area; 
$P_{a}-$ the urban population of the agglomeration [21].

The level of this indicator depends on the presence of satellite cities and the population in them, respectively, the results obtained differ significantly. For the Mykolayiv agglomeration this indicator is also equal 0 because of existence in agglomeration of only one city.

The obtained results showed that the Odessa agglomeration has already taken a fairly stable position and continues to develop, and Kherson is in the initial stage of development, but has prospects for development with an increase in the population of this agglomeration. To receive the status of the formed agglomeration to the Mykolayiv area it is extremely important to carry out a number of territorial and administrative transformations that has to provide also growth of the population in agglomeration.

In modern economic conditions, with the closure of most industries, high unemployment there is a need for economic reorientation of suburban areas, namely the revitalization of former industrial facilities for shopping and entertainment purposes, the creation of new recreational areas, which not only has an economic effect but also creates a favourable image of the territory, giving impetus to active investment development [22, 23].

The next trend, which can be noted by studying the processes of agglomerations of the Black Sea region, is the recreational and economic interaction between recreational complexes within settlements and between them. There is a formation of centres of attraction of tourist and recreational resources in the form of resort towns or large tourist centres with their subsequent absorption of small nearby settlements or the association of relatively small.

However, agglomeration processes with a recreational vector of development tend to conflict with the recreational, residential and environmental components.

It should also be noted that the peculiarity of recreational agglomerations is the presence of special structural elements, such as historical, architectural, cultural monuments; transport accessibility; developed local infrastructure.

The formed set of interconnected recreational centres requires a significant amount of labour, material and technical resources and becomes a pole of gravity for settlements that are not part of the recreational agglomeration and often do not perform any recreational functions, but ensure the efficiency of the entire system [24, 25].

\section{Discussions and conclusion}

The main way to solve a set of social problems in recreational urban areas is to eliminate their sources, in the development of social infrastructure taking into account recreational peaks in the population, increasing local interest in tourism development, improving methods of managing flows and behaviour of tourists and implementing security measures.

A set of these measures is necessary for the sustainable development of recreation in large cities. However, world experience indicates the need for the development of recreational areas in the direction of the territorial division of recreational and residential space. For example, the places of residence of local residents are located away from recreational areas, hotel complexes and relevant infrastructure. Recreational agglomerations on the Black Sea coast, for example considering the Odessa agglomeration in the summer, are very congested, unfavourable infrastructure, transport situation, environmental problems are closely intertwined with engineering, due to chaotic construction, especially high-rise buildings, areas adjacent to the coastal strip and highway. As a result, environmental, social, transport, engineering and other problems are exacerbated, even after some infrastructural changes. However, the active construction of the suburban area along 
the coast continues. This trend may lead to stagnation in the development of the recreational complex in the next few years.

Hence the need to develop new socio-economic, urban approaches to sustainable development of recreational agglomerations.

\section{References}

1. Rudenko, L., Savchuk, I. (2013). Ukraine: changes in urban space. Ukrainian Geographical Journal, 2, 48-56.

2. Komarnyts'ka, H., Shypulina, Y., Illyashenko, N. (2017). The impact of urbanization on the innovative development of the regions of Ukraine. Marketing and Innovation Management, 3, 336-345.

3. Horcher, D., De Borger, B., Seifu, W., Graham, D. (2020). Public transport provision under agglomeration economies. Regional science and urban economics, 81, 103503.

4. Babayev, V. (2003). Efficiency of the system of local self-government of the big city. Theory and practice of management of social systems: philosophy, psychology, pedagogics, sociology, 2, 3-9.

5. Boze, E. (2007). Urban agglomeration: old name - new content. Russian expert review, 4-5.

6. McKnight, M., Gibbs, B., Sanders, S., Cope, M., Jackson J., Park P. (2019). Small towns and urban centers: The relationship of distance and population size to community satisfaction. Community Development, 50(4), 389-405.

7. Rosenthal, S., Strange, W. (2020) How Close Is Close? The Spatial Reach of Agglomeration Economies. Journal of economic perspectives, 34(3), 27-49.

8. Combes, P. (2000). Economic structure and local growth: France, 1984-1993. Journal of urban economics, 47(3), 329-355.

9. Storper, M. (2010) Agglomeration, trade, and spatial development: bringing dynamics back in. Journal of regional science, 50 (1), 313-342.

10. Baudino, M. (2020). Rural-to-urban migration in developing economies: characterizing the role of the rural labor supply in the process of urban agglomeration and city growth. Annals of regional science.

11. Karas, O. (2019). Strategic directions for the design, development, and expansion of transport infrastructure in Ukraine. Science and Innovation, 15(6), 23-32.

12. Faggio G., Silva O., Strange C W. (2020). Tales of the city: what do agglomeration cases tell us about agglomeration in general? Journal of Economic Geography, 20(5), 1117-1143.

13. Wang, F., Fan, W. N., Liu, J., Wang, G., Chai, W. (2020). The effect of urbanization and spatial agglomeration on carbon emissions in urban agglomeration. Environmental science and pollution research, 27(19), 24329-24341.

14. Peters, J. (2020). Dynamic agglomeration economies and learning by working in specialised regions. Journal of economic geography, 20(3), 629-651.

15. Du, J., Vanino, E. (2020). Agglomeration externalities of fast-growth firms, Regional Studies, 54(10), 1323-1327.

16. Kostynets, I., Kostynets, V., Baranov. V. (2020). Pent-up demand effect at the tourist market. Economics \& Sociology, 2(13), 279-288.

17. Kourtit, K., Nijkamp, P. (2019). Creative actors and historical-cultural assets in urban regions. Regional Studies, 53(7), 977-990. 
18. Palyvoda, O., Karpenko, O., Vlasova, V., Bondar, N., Mishulina. O. (2020). Evaluation of seaports' investment attractiveness. Investment Management and Financial Innovations, 17(3), 160-174.

19. Shevchenko, H., Petrushenko, M., Burkynskyi, B., Khumarova, N., Opanasiuk Y., (2020). Management of wellness and recreation in urban agglomerations. Problems and Perspectives in Management, 18(1), 231-241.

20. Gorun, V. (2013). Assessment of recreational and resource potential of the territory Odessa region. Visnyk of the lviv University. series geography. 43(1), 24-31.

21. Lappo, G., Polyan, P., Selivanova, T. (2007). Agglomerations of Russia in the XXI century. Bulletin of the Foundation for Regional Development of the Irkutsk region. 1, 45-52.

22. Radziejowska, A., Sagan, J. (2019). Analysis of the preparatory phase of a construction investment in the area covered by revitalization. Open engineering, 9(1), 415-419.

23. Konior, A., Pokojska, W. (2020). Management of Postindustrial Heritage in Urban Revitalization Processes. Sustainability, 12(12), 1-19.

24. Yakovenko, I. (2018). Structural and dynamic features of recreational agglomeration. Geopolitics and eco-geodynamics of regions, 4(14), 5-15.

25. Piacentino, D., Aronica, M., Giuliani, D., Mazzitelli, A. (2020). The effect of agglomeration economies and geography on the survival of accommodation businesses in Sicily. Spatial economic analysis, 1-18. 